\title{
PENGARUH PENAMBAHAN KARAGENAN Eucheuma cottonii TERHADAP KARAKTERISTIK EKADO IKAN NILA
}

\section{THE EFFECT OF Eucheuma Cottonii CARRAGEENAN ON THE CHARACTERISTICS OF TILAPIA EKADO}

\author{
Yuliati H. Sipahutar ${ }^{1 *}$, Muhamad Rahman ${ }^{1}$, Tina FC. Panjaitan ${ }^{2}$ \\ ${ }_{1}^{1}$ Politeknik Ahli Usaha Perikanan Jakarta, JI. AUP No.1 Pasar Minggu, Jakarta, Indonesia \\ 2Politeknik Kelautan dan Perikanan Karawang, Jl. Baru Tanjungpura, Karangpawitan, Karawang Barat \\ Karawang, Indonesia \\ *Korespondensi: yuliati.sipahutar@gmail.com (YH Sipahutar) \\ Diterima 22 Juli 2020 - Disetujui 27 Agustus 2020
}

\begin{abstract}
ABSTRAK. Penelitian ini bertujuan untuk mendapatkan pengaruh penambahan jumlah karagenan Eucheuma cottoni dalam pengolahan ekado ikan nila. Penelitian ini dilakukan menggunakan metode rancangan acak lengkap dengan perlakuan $0 \%, 2,5 \%, 5 \%, 7,5 \%, 10 \%$. Analisis data menggunakan ANOVA. Kualitas ekado ditentukan berdasarkan hedonik dan kualitas kimianya. Hasil penelitian menunjukkan bahwa penambahan karagenan Eucheuma cottonii berpengaruh signifikan terhadap nilai hedonik dengan parameter kenampakan tekstur, dan kualitas kimia dengan parameter kadar air, kadar abu, dan kadar protein, sedangkan dalam rasa, bau, penampilan dan kadar lemak tidak berpengaruh signifikan. Hasil terbaik untuk ekado dengan penambahan karagenan Eucheuma cottonii sebesar 5\%, dengan nilai kenampakan 7,6, rasa 6,26, bau 6,95, tekstur 7,86, dan nilai kimia kadar air 66,98\%, kadar abu 4,165\%, kadar protein 15,2\%, kadar lemak 2,05\%. Penambahan karagenan Eucheuma cottoni sebagai bahan tambahan pangan pada ekado dapat meningkatkan tekstur ekado.
\end{abstract}

KATA KUNCI: Karakteristik kimia, hedonik, bahan tambahan pangan, ekado, tepung Eucheuma cottonii, ikan nila

ABSTRACT. This research was aimed to observe the effect of using foos additives from Eucheuma cottonii carrageenan in tilapia fish processing. This research was conducted using a completely randomized design method with treatments of $0 \%, 2.5 \%, 5 \%, 7.5 \%, 10 \%$. Data analysis using ANOVA. The quality of the ekado was decided based on the hedonist and the chemical quality. The results showed that the addition of Eucheuma cottonii carrageenan had a significant effect on the hedonist value with appearance, texture and chemical quality parameters with the parameters of water content, ash content, and protein content, while the taste, odor, appearance and fat content had no significant effect. The best results for ekado with the addition of Eucheuma cottonii carrageenan by $5 \%$, with appearance value of 7.6, taste 6.26 , odor 6.95 , texture 7.86 , and chemical value of water content $66.98 \%$, ash content $4.165 \%, 15.2 \%$ protein content, $2.05 \%$ fat content. The addition of Eucheuma cottonii carrageenan as an ekado additive improves the texture of the ekado.

KEYWORDS: Chemical characteristics, hedonist, food additives, ekado, Eucheuma cottonii carrageenan powder, tilapia fish

\section{Pendahuluan}

Karagenan merupakan salah satu komoditas ekspor dan utama program revitalisasi perikanan berperan penting dalam peningkatan kesejahteraan masyarakat. Produksi karagenan pada tahun 2017 turun dibandingkan dengan tahun-tahun sebelumnya, menurut data yang diumumkan Ditjen Perikanan 
Budidaya Kementrian Kelautan dan Perikanan menyebutkan produksi karagenan sepanjang bulan Januari-Oktober 2017 hanya 8,2 ton. Angka ini masih tertinggal jauh dari kinerja 2016 yang mencapai 11,1 ton (Salim \& Ernawati, 2015).

Karagenan merupakan polisakarida yang diekstraksi dari beberapa spesies rumput laut atau alga merah (rhodophyceae). Karagenan adalah galaktan tersulfatasi linear hidrofilik. Polimer ini merupakan pengulangan unit disakarida. Galaktan tersulfatasi ini diklasifikasi menurut adanya unit 3,6anhydro galactose (DA) dan posisi gugus sulfat (Desiana \& Hendrawati, 2015) Hasil penelitian (Chairita, 2008), menunjukkan bahwa karagenan mempunyai peranan yang sangat penting dan dapat diaplikasikan pada berbagai produk sebagai pembentuk gel, bahan pengental, pengikat, pengemulsi dan lain-lain. Salah satunya untuk memperbaiki tekstur dan kekenyalan pada bakso ikan.

Pemanfaatan karagenan dapat dimaksimalkan dengan diverfikasi produk olahan karagenan yang merupakan salah satu upaya untuk meningkatkan daya guna dan nilai ekonomis dari karagenan (Astawan, 2004). Salah satu usaha diversifikasi tersebut adalah dengan cara mengolah karagenan jenis Eucheuma cottonii menjadi tepung, dimana karagenan dalam bentuk tepung dapat dikembangkan menjadi berbagai produk olahan makanan. Salah satu jenis produk makanan yang saat ini sering dikonsumsi masyarakat mulai dari anak-anak hingga dewasa adalah makanan yang pengolahannya cepat dan praktis yaitu ekado.

Ekado adalah produk olahan yang dibuat dari daging ikan yang dicincang dengan penambahan tepung dan bumbu-bumbu. Spesifikasi dari produk ini adalah adonan daging ikan dibungkus dengan kulit pangsit dan dibentuk seperti kantong yang bagian atasnya di ikat dengan daun kucai. Menurut (Saparinto, 2011) Ekado merupakan makanan yang dibungkus dengan adonan kulit pangsit dan merupakan produk yang siap untuk dihidangkan (ready to serve). Ekado dapat dibuat dari fillet ikan nila. Potensi ikan nila sebagai bahan baku ekado cukup besar karena banyak budidaya yang dilakukan ditamabak-tambak masyarakat maupun pengusaha-pengusaha pembudidaya lainnya. Penelitian ini bertujuan mengetahui penambahan bahan tambahan tepung karagenan Eucheuma cottonii terhadap karakteristik mutu ekado.

\section{Bahan dan Metode}

Penelitian dilakukan bulan Februari sd April 2018, bertempat di Workshop Pengolahan, Laboratorium Kimia Pangan, dan Laboratorium Mikrobiologi, Sekolah Tinggi Perikanan Jakarta. Metode penelitian yang digunakan bersifat eksperimental, yaitu dengan melakukan percobaan pembuatan ekado dengan penambahan karagenan. Rancangan yang digunakan adalah rancang acak lengkap (RAL) non faktorial dengan 4 taraf perlakuan, yaitu tanpa penambahan karagenan $0 \%$, penambahan karagenan 2,5\%, penambahan karagenan $5 \%$, penambahan karagenan $7,5 \%$ dan penambahan karagenan $10 \% \%$ Perhitungan jumlah karagenan dihitung dari jumlah daging ikan. Perlakuan diulangan sebanyak 3 kali, sehingga satuan percobaanya adalah 12.

Proses pembuatan ekado mengacu pada SNI 7768:2013 Siomay Ikan dengan sedikit modifikasi (Badan Standarisasi Nasional, 2013b). Parameter uji hedonik menggunakan analisis uji Kruskal-Wallis. Hasil yang signifikan dilanjutkan dengan uji mutiple perbandingan (Sugiyono, 2007). Uji hedonik adalah metode uji yang digunakan untuk mengukur tingkat preferensi untuk suatu produk dengan menggunakan lembar penilaian Skala hedonik yang digunakan berkisar 1-9. Sosis dinilai oleh 30 panelis yang tidak terlatih (Badan Standarisasi Nasional, 2011).

Analisis dilakukan secara deskriptif. Parameter uji kimia adalah kadar air (Badan Standarisasi Nasional, 2015), abu (Badan Standarisasi Nasional, 2010), lemak (Badan Standarisasi Nasional, 2006a), dan protein (Badan Standarisasi Nasional, 2006b). Analisis menggunakan ANOVA kemudian diikuti oleh BNJ atau Tes Tukey untuk hasil yang signifikan (Ghozali, 2007). 


\section{Hasil dan Pembahasan}

Pengujian mutu dilakukan pada 5 konsentrasi penambahan karagenan yang berbeda pada ekado ikan nila. Pengujian ini bertujuan mengetahui pengaruh penambahan karagenan dengan melakukan uji hedonic dan kimia. Pada uji hedonic panelis dimintakan tanggapan pribadinya tentang kesukaan atau sebaliknya (ketidaksukaan). Disamping panelis mengemukakan tanggapan senang, suka atau kebalikannya, mereka juga mengemukakan tingkat kesukaannya (Badan Standarisasi Nasional, 2011).

\subsection{Uji Hedonik (Kenampakan, Bau, Rasa dan Tekstur)}

Hasil uji hedonik ekado ikan nila dengan penambahan karagenan dapat dilihat pada Tabel 1.

Tabel 1. Hasil Pengujian Hedonik Ekado Ikan Nila

\begin{tabular}{ccccc}
\multirow{2}{*}{ Perlakuan } & \multicolumn{4}{c}{ Parameter } \\
\cline { 2 - 5 } & Kenampakan & Bau & Rasa & Tekstur \\
\hline $0 \%$ & $6,97 \pm 1,52^{\mathrm{a}}$ & $6,6 \pm 1,61^{\mathrm{a}}$ & $6,95 \pm 1,51^{\mathrm{a}}$ & $6,15 \pm 1,89 \mathrm{a}$ \\
$2.5 \%$ & $7,26 \pm 1,29^{\mathrm{ab}}$ & $6,66 \pm 1,65^{\mathrm{a}}$ & $6,93 \pm 1,61^{\mathrm{a}}$ & $7,26 \pm 1,41^{\mathrm{b}}$ \\
$5 \%$ & $7,6 \pm 1,21^{\mathrm{b}}$ & $6,95 \pm 1,37^{\mathrm{a}}$ & $7,26 \pm 1,23^{\mathrm{a}}$ & $7,86 \pm 1,17^{\mathrm{c}}$ \\
$7,5 \%$ & $7,33 \pm 1,28^{\mathrm{ab}}$ & $6,64 \pm 1,68^{\mathrm{a}}$ & $6,95 \pm 1,40^{\mathrm{a}}$ & $7,66 \pm 1,47^{\mathrm{bc}}$ \\
\hline
\end{tabular}

Keterangan : Notasi yang sama menunjukkan tidak berbeda nyata

Uji Kenampakan tertinggi dengan nilai 7,6 adalah ekado dengan penambahan karagenan $5 \%$ Sedangkan untuk nilai terendah adalah dengan penambahan karaginan $0 \%$ dengan nilai rata-rata 6,97. Analisa Kruskal-Wallis menunjukkan bahwa tidak ada perbedaan yang signifikan $(P>0,05)$ dalam uji hedonis dari kenampakan ekado ikan nila. Evaluasi penampilan ekado secara umum mencakup semua kriteria yang diuji oleh organoleptik yang meliputi bentuk bulat, kebersihan, kerapian, kerataan warna, dan kecemerlangan. Hasil ini sejalan dengan hasil penelitian Nurhuda, Junianto, \& Rochima (2017), tentang penambahan karagenan pada bakso ikan nila merah yang juga menunjukkan hasil yang berbeda nyata pada kriteria kenampakkan. Berdasarkan hasil penelitian Santoso (2007), perlakuan penambahan konsentrasi karagenan dapat meningkatkan kekuatan gel sehingga penampakan ekado lebih kompak dan berisi. Menurut Arumsari, Darmanto, \& Riyadi (2013), menambahkan konsumen akan lebih menyukai produk dengan bentuk yang rapi, bagus, dan utuh dibandingkan dengan produk yang kurang rapi dan tidak utuh.

Uji bau tertinggi dengan yaitu 6,95 dengan penambahan karagenan $5 \%$ dan nilai terendah dengan konsentrasi karagenan $0 \%$ yaitu sebesar 6,16. Analisa Kruskal wallis menunjukkan bahwa konsentrasi karagenan tidak berpengaruh terhadap bau ekado. Bau-bauan lebih kompleks dari pada rasa dan kepekaan indera pembauan biasanya lebih tinggi dari indera pencicipan (Buckle A. et al., 2009). Bau yang didapat dari ekado berasal dari kulit kembang tahu sehingga tidak memberikan pengaruh, aroma juga berasal dari bumbu-bumbu seperti bawang bombay, lada berfungsi sebagai penambah aroma pada produk yang dihasilkan dan meningkatkan citarasa. Aroma makanan banyak menentukan kelezatan makanan dan cita rasa (Winarno, 2014). Aroma merupakan sensasi bau yang timbul karena rangsangan senyawa kimia (De Man, 1997).

Uji rasa tertinggi dengan yaitu 7,27 pada penambahan karagenan $5 \%$ dan yang terendah pada ekado dengan konsentrasi karagenan 2,5\% yaitu sebesar 6,93. Analisa Kruskal wallis menunjukkan bahwa konsentrasi tepung karagenan tidak berpengaruh terhadap rasa ekado. Rasa pada ekado ikan dipengaruhi oleh komponen-komponen yang terdapat didalam ekado ikan seperti protein. Menurut De Man (1997), cita rasa makanan dipengaruhi oleh komponen-komponen yang terdapat didalam makanan seperti protein, lemak, dan karbohidrat yang menyusunnya. 
Uji Tekstur tertinggi yaitu 7,87 pada penambahan tepung karagenan $5 \%$ dan yang terendah dengan penambahan tepung karagenan $0 \%$ dengan nilai yaitu 6,16. Analisa Kruskal wallis menunjukkan bahwa konsentrasi tepung karagenan berpengaruh terhadap tekstur ekado. Hal ini karena karagenan mampu menghasilkan tektur yang cukup baik pada ekado ikan sehingga teksturnya menjadi lebih kompak (Sipahutar et al., 2020). Berdasarkan penelitian Wiraswanti, Erungan, \& Zahiruddin (2008), pengaruh penambahan karagenan berbeda nyata terhadap bakso ikan yang dihasilkan. Hal ini karena karagenan memiliki kemampuan menghasilkan tekstur yang cukup baik. Penggunaan karagenan dimaksudkan untuk memperbaiki tekstur produk. Karagenan mampu melakukan insteraksi dengan makromolekul yang bermuatan misalnya protein, sehingga mempengaruhi peningkatan viskositas, pembentukan gel, pengendapan dan stabilisasi (Supriyantini, Santosa, \& Dermawan, 2017).

\subsection{Uji Kimia}

Uji kimia dilakukan untuk mengetahui kandungan kimia ekado ikan nila dengan penambahan karagenan. Uji kimia meliputi kadar air, kadar abu, kadar protein dan kadar lemak. Hasil uji kimia ekado dengan konsentrasi tepung karagenan yang berbeda dapat dilihat pada Tabel 2.

Tabel 2. Hasil Uji Kimia Ekado Ikan Nila

\begin{tabular}{ccccc}
\multirow{2}{*}{ Perlakuan } & \multicolumn{4}{c}{ Komponen Kimia } \\
\cline { 2 - 5 } & Air & Abu & Protein & Lemak \\
\hline $0 \%$ & $67,45 \pm 0,16 \mathrm{a}$ & $4,88 \pm 1,20 \mathrm{a}$ & $17,08 \pm 0,37 \mathrm{a}$ & $1,2 \pm 0,03 \mathrm{a}$ \\
$2,5 \%$ & $69,34 \pm 0,72 \mathrm{a}$ & $5,68 \pm 0,03^{\mathrm{a}}$ & $14,985 \pm 0,11 \mathrm{a}$ & $2,915 \pm 1,37 \mathrm{a}$ \\
$5 \%$ & $66,98 \pm 2,33 \mathrm{a}$ & $4,165 \pm 0,28 \mathrm{a}$ & $15,2 \pm 0,99 \mathrm{ab}$ & $2,005 \pm 0,37 \mathrm{a}$ \\
$7,5 \%$ & $69,67 \pm 0,93 \mathrm{a}$ & $4,08 \pm 0,27 \mathrm{a}$ & $14,535 \pm 0,35^{\mathrm{a}}$ & $3,455 \pm 1,76 \mathrm{a}$ \\
\hline
\end{tabular}

Keterangan: Notasi yang sama menunjukkan tidak berbeda nyata

Uji kadar air tertinggi pada ekado dengan perlakuan 2,5 sebesar $69,34 \%$, sedangkan nilai terendah terdapat pada perlakuan penambahan tepung karagenan $0 \%$ sebesar $66,34 \%$. Hasil anova menunjukkan bahwa konsentrasi tepung karagenan tidak berpengaruh nyata terhadap kadar air ekado. Hal ini karena tepung karagenan bersifat hidrofilik yaitu dapat mengikat air. Menurut (Supriyantini et al., 2017), tepung karagenan memiliki sifat mampu mengikat kuat air, senyawa-senyawa polar dan non polar sehingga dapat membentuk gel. Ditambahkan oleh (Distantina, Fadilah, Rochmadi, Fahrurrozi, \& Wiratni, 2010), karagenan berfungsi untuk membentuk jaringan tiga dimensi bersama gula dan air dalam kondisi yang sinergis, dengan terbentuknya jaringan tiga dimensi maka air akan terjebak dan tidak mudah keluar. Kemampuan daging mengikat air disebabkan oleh adanya protein otot. Sekitar $34 \%$ dari protein ini larut dalam air (Desrosier, 1987). Bagian-bagian utama protein daging berupa bahan struktur. Hanya sekitar $3 \%$ dari kemapuan otot mengikat air total disebabkan oleh protein yang larut air (De Man, 1997).

Uji kadar abu tertinggi pada dengan perlakuan 2,5\% yaitu sebesar $5,68 \%$ dan yang terendah pada konsentrasi $7,5 \%$ yaitu sebesar $4,08 \%$. Hasil analisis anova menunjukkan bahwa konsentrasi tepung karagenan tidak berpengaruh nyata terhadap kadar abu ekado. Hal ini karena penggunaan $\mathrm{KCl}$ pada proses pembuatan karagenan. Kadar abu adalah sisa proses pembakaran dimana bahan-bahan organik terbakar tetapi zat anorganiknya tidak. Kadar abu menggambarkan banyaknya mineral yang tidak terbakar menjadi zat yang menguap (Wardayanti, 2004). Proses pemurnian yang dilakukan dengan menambahkan $\mathrm{KCl}$, alkohol dan pembekuan. Metode presipitasi dengan $\mathrm{KCl}$ secara ekonimis lebih murah, tetapi karagenan yang dihasilkan memiliki kadar abu tinggi (Diharmi, 2016). Kadar abu adalah suatu bahan pangan yang menunjukkan banyaknya mineral yang terikat dalam suatu bahan (Winarno, 2014) 
Uji kadar protein tertinggi pada ekado dengan perlakuan $0 \%$ yaitu $17,08 \%$ dan hasil terendah pada $7,5 \%$ yaitu $14,535 \%$. Hasil analisis anova menunjukkan bahwa konsentrasi tepung karagenan tidak berpengaruh nyata terhadap kadar protein ekado. Hal ini karena kemampuan karagenan dalam mengikat air sehingga dapat menahan protein yang dapat larut dalam air saat pengukusan. Menurut (Yakhin, Santoso, \& Tirtajaya (2008), penambahan berbagai konsentrasi karagenan berpengaruh pada protein bakso ikan. Karagenan akan mengikat air bebas dan menahan protein yang dapat larut dalam air saat perebusan. Hal ini menyebabkan kandungan protein bakso ikan cenderung naik seiring penambahan konsentrasi karagenan (Winarno, 2014). Ditambahkan oleh (Hapsari, 2011) reaksi tepung karagenan dengan protein disebabkan oleh adanya gugus ester sulfat yang bermuatan negatif dengan residu karboksilat pada asam amino yang bermuatan positif. Selain itu juga disebabkan oleh gugus hidroksil yang bermuatan negatif pada tepung karagenan berikatan dengan gugus amin pada protein (Muarif, Sukirno, \& Suparmi, 2017).

Uji Lemak tertinggi pada ekado dengan perlakuan $7,5 \%$ yaitu sebesar $3,46 \%$ sedangkan hasil terendah pada konsentrasi $0 \%$ yaitu 1,20\%. Hasil analisis anova menunjukkan bahwa konsentrasi tepung karagenan tidak berpengaruh nyata terhadap kadar lemak ekado. Hal karena lemak tidak larut dalam air sehingga lemak masih tetap berada dalam matriks gel ikan (Winarno, 2014). Menurut Sipahutar \& Siregar (2016), menambahkan bahwa karagenan dapat berfungsi sebagai water binding (pengikat) air dari pada sebagai pengikat lemak. Hal ini dapat ditunjukkan dengan tidak larutnya karagenan dalam lemak, tetapi karagenan dapat berikatan dengan protein. Lemak akan diikat oleh kutub positif protein. Penambahan karagenan menyebabkan protein akan lebih mengikat air sehingga ikatan lemak oleh protein menjadi berkurang (Desrosier, 1987). Kerusakan lemak pada bahan makanan dapat mengakitkan bau tengik, dan rasa yang tidak enak, sehingga mutu dan nilai gizinya turun (Syapitriani, Novieta, \& Irmayani, 2019).

\subsection{Uji Mikrobiologi ALT}

Analisis mikrobiologi yang dilakukan adalah penentuan Angka Lempeng Total (ALT) dengan metode tuang. Prinsip metode ini adalah sel bakteri dalam sampel ditumbuhkan pada medium agar dan diinkubasi.

Tabel 3. Hasil Pengujian Angka Lempeng Total (ALT) Ekado Ikan Nila

\begin{tabular}{cc}
\hline Perlakuan & Rata-Rata Pengujian ALT ( koloni/gr ) \\
\hline $0 \%$ & $2,6 \times 10^{3}$ \\
$2,5 \%$ & $3,3 \times 10^{3}$ \\
$5 \%$ & $2,4 \times 10^{3}$ \\
$7,5 \%$ & $2,4 \times 10^{3}$ \\
\hline
\end{tabular}

Pada tabel diatas menunjukkan nilai ALT ekado berkisar antara 2,4 $\times 10^{3}$ sampai dengan $3,3 \times$ 103. Hal ini sejalan dengan penelitian (Sipahutar \& Siregar, 2016) hasil uji ALT produk bakso ikan tuna adalah 27,2 x 10 koloni/gram. Hal ini menunjukkan bahwa produk ekkado dengan penambahan konsentrasi tepung karagenan tersebut masih memenuhi syarat untuk dikonsumsi. Produk ekado tersebut masih di bawah ambang batas maksimal nilai ALT produk jadi yaitu $5 \times 10^{4}$ (Badan Standarisasi Nasional, 2013a)

\section{Kesimpulan}

Kesimpulan dari penelitian menunjukkan bahwa penambahan karagenan Eucheuma cottonii berpengaruh signifikan terhadap nilai hedonik dengan parameter kenampakan tekstur, dan kualitas kimia dengan parameter kadar air, kadar abu, dan kadar protein, sedangkan dalam rasa, bau, penampilan dan kadar lemak tidak berpengaruh signifikan. 


\section{DAFTAR PUSTAKA}

Arumsari, M. D., Darmanto, Y., \& Riyadi, P. H. (2013). Pengaruh Perbedaan Konsentrasi Tepung Kentang (Solanum Tuberosum) terhadap Karakteristik Pasta dari lkan Air Tawar, Payau dan Laut. Jurnal Pengolahan dan Bioteknologi Hasil Perikanan, 2(5), 108-117.

Astawan, M. (2004). Pemanfaatan Karagenan (Eucheuma Cottonii) Untuk Meningkatkan Kadar lodium dan Serat Pangan pada Selai dan Dodol. Jurnal Teknologi dan Industri Pangan, 15(1).

Badan Standarisasi Nasional. Penentuan Kadar Lemak pada Produk Perikanan (2006). Indonesia.

Badan Standarisasi Nasional. Penentuan Kadar Protein pada Produk Perikanan (2006). Indonesia.

Badan Standarisasi Nasional. Penentuan Kadar Abu Pada Produk Perikanan (2010). Indonesia.

Badan Standarisasi Nasional. Petunjuk Pengujian Organoleptik dan atau Sensori pada Produk Perikanan (2011). Indonesia.

Badan Standarisasi Nasional. Penentuan Angka Lempeng Total (ALT) pada Produk Perikanan (2013). Indonesia.

Badan Standarisasi Nasional. Siomay Ikan (2013). Indonesia.

Badan Standarisasi Nasional. Cara uji kimia - Bagian 2 : Pengujian kadar air pada produk perikanan (2015). Indonesia.

Buckle A., Edwards R, A., ., Eleet G, H., ., Wootton, Purnomo, H., \& Adiono. (2009). Ilmu Pangan. Jakarta: Penerbit Universitas Indonesia.

Chairita. (2008). Karakteristik Bakso Ikan dari Campuran Surimi Ikan Layang (Decapterus spp) dan Ikan Kakap Merah (Lutjanus sp) Pada Penyimpanan Suhu Dingin. Institut Pertanian Bogor.

De Man, J. M. (1997). Kimia Makanan (2 ed.). Bandung: Institut Teknologi Bandung.

Desiana, E., \& Hendrawati, T. Y. (2015). Pembuatan Karagenan dari Eucheuma Cottonii dengan Ekstraksi KOH Menggunakan Variabel Waktu Ekstraksi. Universitas Muhammadiyah Jakarta.

Desrosier, N. W. (1987). Technology of Food Chemistry. Westport: AVI Publisher, Co inc.Weespot, Connecticut.

Diharmi, A. (2016). Karakteristik Fisiko-Kimia Karagenan Merah (Eucheuma Spinosum) dari Perairan Nusa Penida, Sumenep dan Takalar. Institut Pertanian Bogor.

Distantina, S., Fadilah, Rochmadi, Fahrurrozi, M., \& Wiratni. (2010). Proses Ekstraksi Karagenan dari Eucheuma Cottonii. In Seminar Rekayasa Kimia dan Proses (hal. 1-6).

Ghozali, I. (2007). Aplikasi Analisis Multivariate dengan Program SPSS. Universitas Diponegoro.

Hapsari, A. P. (2011). Formulasi dan Karakteristik Minuman Fungsional Fruity Jelly Yogurt Berbasis Kappa-Karagenan Sebagai Sumber Serat Pangan. Institut Pertanian Bogor.

Muarif, D., Sukirno, \& Suparmi. (2017). Pengaruh Penambahan Jumlah Karagenan Berbeda Terhadap Mutu Bakso Ikan Lomek (Harpodon Neherreus).

Nurhuda, H. S., Junianto, \& Rochima, E. (2017). Penambahan Tepung Karaginan Terhadap Tingkat Kesukaan Bakso Ikan Manyung. Jurnal Perikanan dan Kelautan, 8(1), 157-164.

Salim, Z., \& Ernawati. (2015). Info Komoditi Karagenan. Jakarta: Al Mawardi Prima.

Santoso, D. (2007). Pemanfaatan Karagenan pada Pembuatan Sosis dari Surimi Ikan Bawal Tawar (Colossoma Macropomum). Institut Pertanian Bogor.

Saparinto, C. (2011). Variasi Olahan Produk Perikanan Skala Industri dan Rumah Tangga. Yogyakarta: Lily Publisher.

Sipahutar, Y. H., \& Siregar, A. N. (2016). Penambahan Konsentrasi Tepung Karagenan Pada Mutu Bakso Ikan Tuna (Thunnus sp.). Jurnal STP (Teknologi dan Penelitian Terapan), 2, 48-55. 
Sipahutar, Y. H., Taufiq, T., Kristiani, M. G. E., Prabowo, D. H. G., Ramadheka, R. R., Suryanto, M. R., \& Pratama, R. B. (2020). The effect of Gracilaria powder on the characteristics of nemipterid fish sausage. IOP Conference Series: Earth and Environmental Science, 404. https://doi.org/10.1088/1755-1315/404/1/012033

Sugiyono. (2007). Metode Penelitian Kuantitatif, Kualitatif dan RE \& D. Bandung: Alfabeta.

Supriyantini, E., Santosa, G. W., \& Dermawan, A. (2017). Kualitas Ekstrak Karaginan Dari Rumput Laut "Kappaphycus alvarezii" Hasil Budidaya Di Perairan Pantai Kartini Dan Pulau Kemojan Karimunjawa Kabupaten Jepara. Buletin Oseanografi Marina, 6(2), 88-93. https://doi.org/10.14710/buloma.v6i2.16556

Syapitriani, E., Novieta, I. D., \& Irmayani. (2019). Penambahan Karagenan (Kappaphycus Alvarezii) Sebagai Bahan Pengenyal Terhadap Kadar Air dan Kadar Garam Bakso Daging Kerbau. In Seminar Nasional Sinergitas Multidisiplin Ilmu Pengetahuan dan Teknologi (Vol. 2, hal. 292-294).

Wardayanti, W. (2004). Mempelajari lota Karaginan (Eucheuma Cottonii) dan Kappa Karaginan (Kappaphycus Alvarezii) Sebagai Sumber Serat untuk Meningkatkan Kekenyalan Mie Kering. Institut Pertanian Bogor.

Winarno, F. G. (2014). Kimia Pangan dan Gizi. Jakarta: Gramedia.

Wiraswanti, I., Erungan, A. C., \& Zahiruddin, W. (2008). Pemanfaatan Karagenan dan Kitosan dalam Pembuatan Bakso Ikan Kurisi (Nemipterus Nematophorus) pada Penyimpanan Suhu Dingin dan Beku. Buletin Teknologi Hasil Perikanan, 11(1).

Yakhin, L. A., Santoso, J., \& Tirtajaya, I. (2008). Pengaruh Penambahan Kappa-Karagenan terhadap Karakteristik Bakso Ikan Nila Hitam (Oreochromis Niloticus) dan Bakso Ikan Lele Dumbo (Clarias Gariepinus). Jurnal IImu dan Teknologi Pangan, 6(1). 
